Journal of Engineering and Applied Sciences 14 (Special Issue 8): 10434-10436, 2019

ISSN: $1816-949 \mathrm{X}$

(C) Medwell Journals, 2019

\title{
Design of Whiteboard Animation Media with Smart Peadagogy Approach in Educational Policy Courses
}

\author{
Muhdi, Achmad Buchori, Arif Wibisono and Yovita Yuliejantiningsih \\ Universitas PGRI Semarang, J1. Dr. Cipto-Lontar No.1 Semarang, Semarang, Indonesia
}

\begin{abstract}
This study aims to obtain a media whiteboard animation that uses a smart peadagogy approach that can be used in learning education policy courses in the education management master's program and it is expected that students can break down the application in school. The procedure for developing learning devices using models developed by Borg and Gall which includes 10 stages, namely, research and information collecting, planning, develop preliminary form of product, preliminary field testing, play product revision, main field testing, operational product revision, operational field testing, final product revision, dissemination and implementation. Practically Borg and Gall state that the development research procedure basically consists of two main objectives, namely: developing products and testing the effectiveness of the product in achieving its objectives.
\end{abstract}

Key words: Peadagogy, management, implementation, planning, development, approach

\section{INTRODUCTION}

The development of learning media is very rapid in the last 10 years, this is very challenging for the world of education in Indonesia, especially, universities in using it in lectures, one of the renewable media such as interactive whiteboard has not been used generally in universities in Indonesia, animation whiteboard is a large touch screen panel that can function as a regular whiteboard or as a computer projector screen that can control images on a computer by touching the panel surface without using a mouse or keyboard. This technology allows users to write or draw on its surface directly and save it to the computer. (Miller and Glover, 2002).

Based on interviews with some lecturers at the state university of Malang and ITS in the Department of Learning Technology and Informatics Engineering obtained data that the majority of universities are still reluctant to use interactive whiteboard media because the price is still quite expensive range of 80 million. However, if viewed functionality for the world of education is very important. Based on relevant studies conducted by Kennewell and Morgan (2003), 95\% of students and teachers observed in the UK stated that interactive whiteboards can add value to learning, although, $76 \%$ feel that with this whiteboard animation will increase their preparation time, like how to learn operate it effectively.

Final result: The specific objective to be achieved in this research and development is to produce animation whiteboard media that can improve the smart pedagogic skills of students.
Relevant research results: These relevant studies related to the research that researchers will do are: research conducted by Miller and Glover (2002) about: the interactive whiteboard as a force for pedagogic change: the experience of the five elementary schools in an English education authority. Information technology in childhood education. Norfolk, Vermont, AACE which shows that elementary school children are greatly helped by their pedagogical ability with interactive whiteboard media.

Research conducted by Kennewell and Morgan (2003) on "Student teacher's experiences and attitudes towards using interactive whiteboard in the teaching and learning of young children". Department of Education, Swansea University of Wales which indicates that wales children are very happy if their teachers use interactive whiteboards in their learning, this is because the objects images, sounds and others can be directly practiced by students.

Research conducted by Mercer et al. (2010) about "can the interactive whiteboard help to provide dialogic space for children's collaborative activity?" shows that the students in the school are very happy with the interactive whiteboard because students can collaborate in the delivery of ideas and ideas directly in front of the class.

The differences in this study with the relevant research above can be shown through the following fishbone (Fig. 1), thus, this study will develop learning media interactive whiteboard to improve student psychomotor skills. 


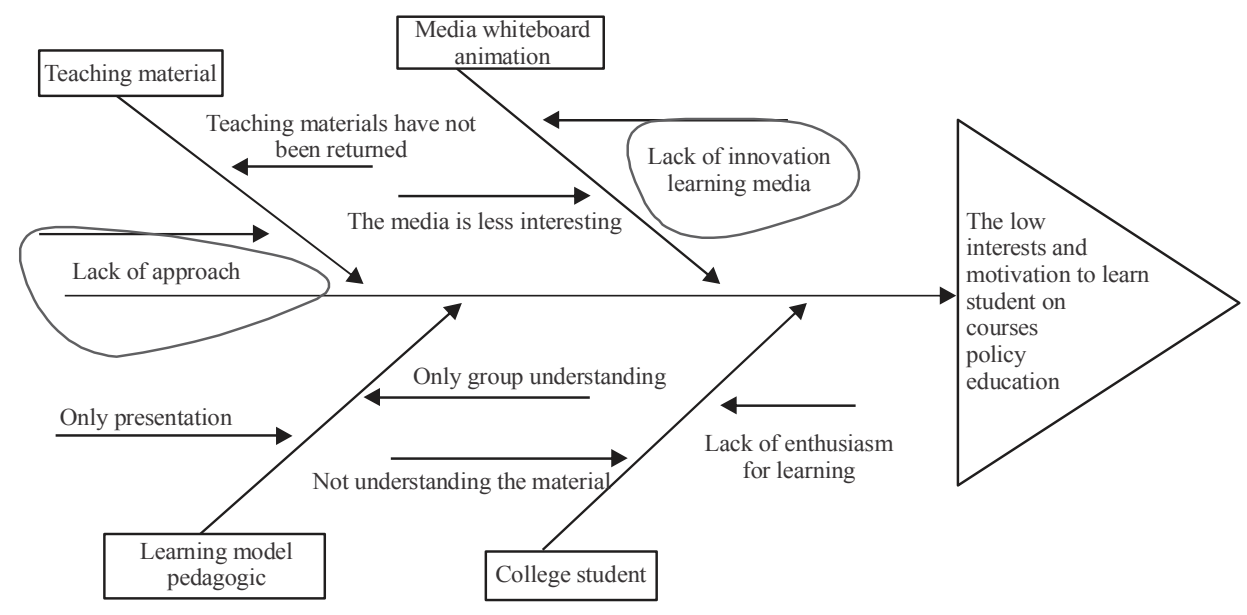

Fig. 1: Difference of study

\section{MATERIALS AND METHODS}

This research includes the type of R\&D (Research and Development) or type of research development. The development carried out is the development of interactive whiteboard with the smart pegagogy. The procedure for developing learning devices using modification models developed by Borg and Gall which includes 10 stages (Fig. 2).

Research and information collecting stage: In this stage, the activities carried out are conducting literature studies that underlie the learning products that will be developed.

Planning stage: In this stage, after the preliminary study is done, the next step is to design the various activities and procedures that will be pursued in research and development of learning products.

Stage develop preliminary form of product: This stage is the design stage of the initial draft interactive learning whiteboard products that have been validated and revised based on the input of experts to produce revision draft 1.

Stage preliminary field testing: The purpose of this stage is to obtain a setting description (application) or feasibility of a product in this case the interactive whiteboard. This preliminary test is limited which only involves two classes. The results of this limited trial were carried out to determine weaknesses in draft 1 and were used as material for revising a product to be developed. Research and information collecting stage. In this stage, the activities carried out are conducting literature studies that underlie the learning products that will be developed.

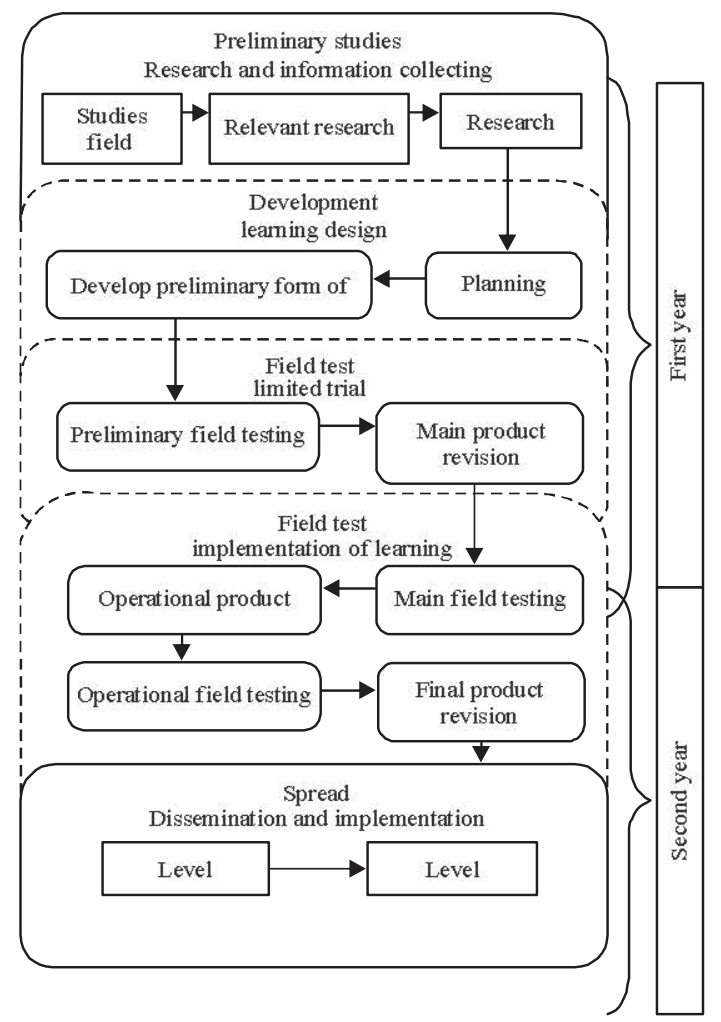

Fig. 2: Modification of Borg and Gall development model scheme

Main product revision: The activity at this stage was to correct weaknesses in draft 1 based on the results of limited trials, so as to produce product improvements called draft 2 .

Method of collecting data: Data collected on the development of whiteboard animation in the form of quantitative data as the principal data and qualitative 
data in the form of suggestions and input from respondents as additional data. The data gives an idea of the feasibility of the developed product.

Data from media experts: In the form of product quality in terms of media aspects, namely: interaction with users, use of text format language, color usage, image quality, sound/music quality, video and illustration quality, use of animation, presentation order and animation whiteboard display.

Data analysis technique: In the data analysis stage, the data is in the form of assessment of instructional media obtained from media validity by some experts and the results of pedagogical skills of the students analyzed for product improvement. The data in the form of the results of the researcher checklist that was obtained at the implementation stage (pretest and post test that had been answered by the child) were analyzed to determine the effectiveness of the product.

\section{RESULTS AND DISCUSSION}

The validation and assessment results of system experts for each aspect are presented in Table 1. The following is a descriptive presentation of the results of expert validation assessment on whiteboard media.

From Table 1, it can be seen for the aspect of media assessment $(89.16 \%)$. All aspects are in the range of $81-100 \%$, so, it can be said to be valid because it has put in a very good criteria position. In the next analysis process conducted an overall analysis in the assessment by the validator obtained data as follows: The sum of all validation scores:

$$
\begin{aligned}
& \text { Percentage }=\sum \frac{1}{\mathrm{n} \times \text { hightest value } \times} \times 100 \% \\
& \text { number of validation }
\end{aligned}
$$

Percentage $=\sum \frac{80+80+42}{46 \times 5 \times 1} \times 100 \%$

Percentage $=-\times 100 \%=87.82 \%$
Table 1: Media expert evaluation results through a validation sheet Validator

\begin{tabular}{lccc}
1 & 2 & 3 & Appropriateness \\
\hline 84.21 & 94.11 & 84.00 & 89.16 \\
Average & & & 89.16 \\
\hline
\end{tabular}

Based on the results of the calculation of the percentage can be seen that the percentage results are $87.82 \%$ after being converted to a scale table, the percentage of achievement 87.82 is in good qualification, so that, the media whiteboard can be said to be valid or feasible to use in lectures.

\section{CONCLUSION}

From the results of the validation and assessment seen from the aspect of material, design and media get an average rating of $89.16 \%$, all aspects are in the range of $81-100 \%$, so, it is said to be valid because it puts it in a very good criteria position. In the analysis process, then the overall analysis in the validator's assessment is obtained percentage calculation data $87.82 \%$ after being converted to scale tables, the achievement percentage of 87.82 is in good qualification, so that, the media whiteboard can be said to be valid or feasible to use in lectures.

\section{REFERENCES}

Kennewell, S. and A. Morgan, 2003. Student teachers experiences and attitudes towards using interactive whiteboards in the teaching and learning of young children. Proceedings of the International Conference on Federation for Information Processing Working Group 3.5 Open Young Children and Learning Technologies (CRPIT'03) Vol. 34, July 1, 2003, Australian Computer Society Inc., Darlinghurst, Australia, ISBN:1-920682-16-3, pp: $65-69$.

Mercer, N., S. Hennessy and P. Warwick, 2010. Using interactive whiteboards to orchestrate classroom dialogue. Technol. Pedagogy Educ., 19: 195-209.

Miller, D. and D. Glover, 2002. The interactive whiteboard as a force for pedagogic change: The experience of five elementary schools in an English education authority. Inf. Technol. Child. Educ. Ann., 2002: 5-19. 